\title{
Mediated discourse analysis in language and sexuality research
}

Book or Report Section

Accepted Version

Jones, R. (2019) Mediated discourse analysis in language and sexuality research. In: Hall, K. and Barrett, R. (eds.) The Oxford Handbook of Language and Sexuality. Oxford University Press. ISBN 9780190212926 doi: https://doi.org/10.1093/oxfordhb/9780190212926.013.4 Available at http://centaur.reading.ac.uk/81525/

It is advisable to refer to the publisher's version if you intend to cite from the work. See Guidance on citing.

To link to this article DOI:

http://dx.doi.org/10.1093/oxfordhb/9780190212926.013.4

Publisher: Oxford University Press

All outputs in CentAUR are protected by Intellectual Property Rights law, including copyright law. Copyright and IPR is retained by the creators or other copyright holders. Terms and conditions for use of this material are defined in the End User Agreement. 


\section{www.reading.ac.uk/centaur}

\section{CentAUR}

Central Archive at the University of Reading

Reading's research outputs online 


\title{
Mediated Discourse Analysis in Language and Sexuality Research
}

\author{
Rodney H. Jones \\ University of Reading \\ (Running word count: 9369)
}

(Running Header: Mediated Discourse Analysis)

\begin{abstract}
This chapter outlines some of the main theoretical principles and analytical procedures of mediated discourse analysis and illustrates how they can be applied to studies of language and sexuality. Where mediated discourse analysis differs from other approaches to language and sexuality is its focus on the concrete social actions that people take in their lives, like putting on a condom or sharing a dick pic. The approach asks how language and other cultural tools that people have available to them make these actions possible, and, how through their actions, people reproduce or 'technologize' these cultural tools so that they can be taken up and used in future actions. Sexuality emerges through a process of making our bodies (and parts of our bodies) meaningful in the ongoing negotiation of mediated actions through processes of entextualization, appropriation, and recontextualization.
\end{abstract}

Keywords: agency, digital technologies, entextualization, mediated discourse analysis

\section{WHAT DOES A 'DICK-PIC’ DO?}

In April of 2015, on the eve of the reauthorization of the US Patriot Act, a law which makes possible a wide range of surveillance activities by the US government against private citizens, the television comedian John Oliver interviewed the famous whistleblower Edward Snowden, 
whose release of thousands of NSA documents brought to the world's attention the extent of the government's domestic espionage operations. Lamenting that the American public did not seem sufficiently engaged in the admittedly complex issue of government surveillance, Oliver attempted to get Snowden to talk about the problem in terms that the 'average American' could understand by asking the question:

'Can they see my dick?'

The point Oliver is making was that if Americans (specifically, American men) thought that the NSA was keeping a dossier of their dick pics, they would be much more concerned about the issue of government surveillance. 'Everything you did only matters if we have this conversation properly,' Oliver tells Snowden, and, in his view, it is the object of the 'dick pic' (and the social practice of which it is a part) that can make talking about surveillance in a way people can understand possible.

This example illustrates a number of important issues related to the study of language and sexuality. The first is the fact that language about sex and sexuality can pop up in all sorts of different contexts and be used for all sorts of different purposes. In this case, for example, a clearly sexual social practice, the exchange of erotic photographs, is recruited into a decidedly non-erotic context - a conversation about the complexities of government surveillance. In fact, it is the very sexual nature of this practice and the kinds of texts it results in that, in Oliver's view, makes possible a productive conversation about the non-sexual topic. In a sense, the subject of government surveillance is 'queered' though its association with the production and distribution of dick pics. At the same time, the practice of sharing of dick pics is also 'queered' by being 
framed not just as a matter of sexuality, but a matter of national security, and even patriotism. After enumerating the different ways the US government might gain access to its citizen's dick pics, Oliver asks Snowden if, in light of this, it might not be a good idea for people to just stop taking pictures of their dicks, prompting the following exchange:

Snowden: ... you shouldn't change your behavior because a government agency somewhere is doing the wrong thing. If we sacrifice our values because we're afraid, we don't care about those values very much.

Oliver: That is a pretty inspiring answer to the question: Hey, why did you just send me a picture of your dick? Because I love America, that's why!

As it turned out, some people took Oliver up on this challenge, staring a Reddit group called DickPics4Freedom, where they posted full frontal images of their erect penises with abandon, with captions such as 'They may take our lives, but they will never take our dicks,' and 'I stand erect from freedom' (Gorenstein 2015), further 'queering' practices of dick pic sharing and state surveillance by mashing them up with a rather 'queer' idea of patriotism, one which ironically indexes traditional associations between patriotism and masculinity (Nagel 1998) and reframes 'freedom' in sexual terms.

What this example reminds us, then, is that sometimes what is most important about discourse about sex and sexuality - whether it comes in the form of spoken words, written texts, or images of things such as dicks - is not what these utterances, texts, and images 'mean', but what people $d o$ with them, and the ways, through these social actions, certain kinds of social identities and social relationships - and certain kinds of 'conversations' -- are made possible, 
sometimes through processes of 'queering action': taking a particular tool (an object, concept, or text) that is usually used to perform one kind of social action and appropriating it to perform a totally different kind of social action, one that undermines or opens up 'fissures' within dominant discourse or ways of seeing the world.

What Oliver's appropriation of the dick pic also reminds us is that no cultural tool is ideologically neutral or free from the relationships of power associated with the social practices it is used to perform. The main reason his insertion of the dick pic into this seemingly incongruous context seems reasonable (albeit humorous) is the dominant discourse of masculine hegemony that underlies the practice of producing and distributing dick pics - a discourse in which there is already the assumption that it is some kind of 'constitutional right' for men to circulate their dick pics at will, free of social censure, a right that it is difficult to imagine would be so explicitly asserted for women who wish to produce and distribute pictures of their bodily parts (see Thurlow this volume).

Finally, perhaps the most obvious thing this example highlights is how much digital technologies have affected practices associated with sex and sexuality (as well as governance and surveillance) and how we communicate in and about those practices. Fifty years ago, the idea that a man would send a photograph of his penis to another person, or that such a photograph might be intercepted by the government, though possible, would have been considered highly irregular, and perhaps even prosecuted under laws prohibiting the use of the postal service for distributing 'obscene' materials (Paul 1961). Today, circulating dick pics, rather than a marginalized sexual practice, is a more or less 'mainstream' social practice, part and parcel of the way sexuality (and language about sexuality) is increasingly mediated through technologies like computers and mobile phones and the ways these technologies facilitate certain 
forms of self-expression. Similarly, digital technologies have also made it possible for entities such as the NSA, but also including a range of internet companies, data brokers, advertisers, and political campaigns to intercept people's everyday communications (along with their dick pics) and use them -- not to punish them for violating obscenity laws, but to sell them sneakers or convince them to vote for a particular presidential candidate (Jones in press).

The purpose of this chapter is to explore ways in which language and sexuality scholars can address the issues brought up by this example- the issue of action: how language and other semiotic systems construct sex and sexuality not just through what they mean but through the concrete social actions people take with them; the issue of mediation -- the fact that, all actions, including actions associated with sex and sexuality, are mediated through cultural tools, which include both language (and other semiotic systems) and physical objects like cell phones and digital cameras; the issue of identity - how what we do with our language, our cell phones, and other cultural tools helps to determine what kind of person we can be and what kind of relationships we can have; and the issue of power - the fact that language and other cultural tools are unequally distributed, and so the kinds of social actions and social identities that are associated with them are also unequally distributed.

The framework I will introduce to explore these issues is called mediated discourse analysis (Norris and Jones 2005; Scollon 2001), an approach that takes as its unit of analysis not discourse, but the social actions that discourse makes possible. In what follows I will briefly introduce the theoretical concepts and analytical procedures that make up this framework, explain their relevance to the study of language and sexuality, and illustrate their application by reviewing a series of studies that explore the effects of media and mediation on people's sexual behavior. 


\section{Mediated Discourse Analysis}

Mediated discourse analysis shares many of the goals of other approaches to the study of language and sexuality discussed in this handbook, especially the desire to understand the interrelationship between language, identity, and social action, and a commitment to understanding the way power works in the reproduction and regulation of sexual practices and sexual identities. Where mediated discourse analysis differs is its focus. Whereas other approaches usually begin with language, ideologies, practices, and identities and asks how they create meaning, mediated discourse analysis begins with the concrete social actions that people take in their lives, like putting on a condom or sharing a dick pic, and asks, first of all, how language, ideologies, practices, identities, and other cultural tools that people have available to them make these actions possible, and, second, how through their actions, people reproduce or 'technologize' these languages, ideologies, practices, identities, and other cultural tools so that they can be taken up and used in future actions. In other words, mediated discourse analysts are interested in how people use discourse as a tool for social action, and how, through social actions, they alter discourse to fit particular kinds of situations and social goals or to operate within the particular constraints their societies impose upon them.

Another way mediated discourse analysis differs from traditional approaches to language and sexuality is that is doesn't necessarily regard language as the 'primary vehicle' through which people circulate cultural ideologies and produce social identities. The social actions that that they perform to do these things also depend on other tools (such as condoms, computers, mobile phones, and dick pics). Rather than automatically privileging the role of language in every action, mediated discourse analysts are concerned with how language interacts with other 
tools, especially material mediational means - objects, physical texts, and the electronic media that often serve as the carriers of language (see also work in other approaches focusing on issues of materiality and embodiment such as Bucholtz \& Hall 2016).

In what follows I will give an outline of the main principles of mediated discourse analysis and how they can be applied to research on language and sexuality, grouping these principles into three main categories: 1) technologies and technologization (what are the 'cultural tools' we have available to take action around sex and sexuality?); 2) mediation, entextualization and display (how these tools make certain kinds of actions and identities more possible than others through the way they enable people to turn their bodies into texts and make them available to others in certain ways?); and appropriation, recontextualization, and the historical body (how does technological mediation affect the degree of control people have over representations of their bodies and sexual practices and ultimately the degree of agency they have to act in the world as sexual/textual beings?). I will explain these concepts with examples from both studies that explicitly use MDA as a theoretical framework, as well as studies of sexuality that do not use MDA per se, but nonetheless exemplify some key aspect of the framework.

\section{TECHNOLOGIES AND TECHNOLOGIZATION}

By beginning with action rather than with language (or 'meaning'), mediated discourse analysis allows analysts to avoid the assumption that we can 'read' meanings from texts by studying these texts outside of their use in concrete, situated actions (Jones and Norris 2005: 9). The danger of this assumption became evident in early work using mediated discourse analysis which attempted to address the spread of HIV among men who have sex with men (MSM) in China in the 1990s (Jones 1999, 2002, 2007a). At that time, urban communities of MSM in China were 
experiencing a dramatic increase in the rate of HIV transmission relative to other vulnerable communities, despite the fact that many members of this community believed that they practiced 'safe sex'. So the question the study began with was, what were the men in question doing when they were having 'safe sex', what sorts of cultural tools (such as public health slogans sexual scripts, social identities, physical places, and objects) did they have available to them to engage in these actions, and how did these tools either enable or constrain their ability to avoid HIV transmission.

The most obvious cultural tool these men had available to them to avoid HIV transmission, of course, was the condom, but after interviewing these men and observing their social interactions it became clear that for many of them using a condom was seen as constraining their ability to avoid HIV transmission rather than enabling it, because it was seen as interfering with their ability to form relationships of trust with their sexual partners and to establish identities as ‘civilized gay men’ (Jones 2007a; Rofel 1999) . Government warnings advising them 'when in doubt, use a condom', made matters even worse, since the state of 'being in doubt' (and showing it by using a condom) was regarded as more 'risky' than the action of unprotected sex.

The reason for this state of affairs was that the cultural tool of the condom had been technologized in a particular way within these communities so that its use resulted in claiming and imputing social identities that members felt put them at risk for HIV transmission rather than protected them from it. The identities they were able to claim by not using condoms were seen as more effective tools for the prevention of HIV.

These observations serve to highlight some important characteristics of cultural tools that are central to mediated discourse analysis and its application to language and sexuality studies. 
i) All actions are mediated through cultural tools, some of which may be material (such as condoms), and some of which may be semiotic (such as public health slogans, sexual scripts, and social identities).

ii) All cultural tools make some actions easier and others more difficult. That is to say, all tools introduce affordances and constraints (Gibson 1986) into the social situations in which they are used. In the example described above, condoms were seen as affording the prevention of HIV transmission, but constraining the formation of the kinds of 'trusting' relationships that government propaganda associated with 'safe sex'.

iii) The affordances and constraints of cultural tools are not just a matter of their inherent material or semiotic qualities, but are also a function of the kinds of social practices and social identities that have adhered to these tools over the course of the multiple social actions they have been appropriated into over time. As tools are used they become associated with other tools within larger 'toolboxes' which might be called 'Discourses' (Gee 2011) or 'ideologies'. In the China of the 1990s, for example, condoms were associated with a discourse of family planning and an ideology of socialist morality in which admitting the possibility of multiple sexual partners was socially problematic. This process by which the affordances and constraints of cultural tools become refined and fixed over time is called technologization (Jones 2002, 2016; Scollon 2001). Technologization can be seen as the way, over time, tools become associated with certain kinds of people, certain kinds of social situations, and certain kinds of uses. In sociolinguistics, 'enregisterment' (Agha 2007) can be seen as 
a kind of technologization: a process by which particular ways of speaking come to be associated with particular kinds of people and particular kinds of social behaviors (Jones 2016a).

iv) The affordance and constraints of any cultural tool are not wholly determinative of how it can be used; social actors exercise considerable creativity in 'bending' and 'blending' tools with other tools in order to make them more suitable for accomplishing particular actions, and these creative adaptations can sometimes result in tools being technologized in new ways. A key concern of mediated discourse analysis is the "tension between the mediational means as provided in the sociocultural setting and the unique contextualized use of these means in carrying out particular concrete actions' (Wertsch 1994: 205).

The most important point here -- and the point at which mediated discourse dovetails with the concerns of other scholars in this volume-is mediated discourse analysts' insistence on viewing sexual ideologies, practices, and identities as inter-connected issues (Bucholtz and Hall 2004: 471) that come together in moments of social practice. Cultural tools are never ideologically neutral: they are 'carriers of social, cultural, and historical formations' (Norris and Jones 2005: 49). Every time somebody appropriates a particular tool, they are invoking the history of its use, situating themselves within a particular Discourse, and claiming for themselves a certain identity associated with that Discourse. In this way, it is through the gradual technologization of cultural tools - even 'mundane' tools like condoms, telephones, and dick pics - within particular communities and societies, that the ideologies governing these communities and societies are produced and reproduced and the identities and relationships that constitute these communities 
and societies are formed. Thus, the action of using a condom or of not using a condom is a crucial site at which certain ideas about 'being gay' (or being 'Chinese' or being 'civilized') are worked out, just as, in the example with which I began this chapter, sending or not sending dick pics becomes a site where ideas about masculinity, privacy, and even citizenship and patriotism come to be debated.

Whereas many other approaches to language and power are interested in how ideologies and identities operate upon speakers, and how evidence of this operation can be uncovered in people's texts and utterances (see for example Fairclough 1992), mediated discourse analysis is interested in how people themselves contribute to the production of ideologies and identities through their everyday actions and the ongoing technologization of cultural tools that these actions entail. It recognizes that the solution to larger problems of power, inequality, and social vulnerability often lie in our attempts to grapple with more concrete, situated problems like how to get our sexual partner to use a condom, for it is through these mundane, situated actions that we build (and transform) our social worlds moment by moment.

\section{MEDIATION, ENTEXTUALIZATION, AND DISPLAY}

It should be clear from the last section that mediated discourse analysis views all sexual activity as mediated. Having sex (not to mention, 'having sexuality') depends upon people having access to certain cultural tools. Some of these tools are material, like condoms and cell phones and sexy underwear, and some are semiotic, like seductive talk, sexual scripts, and sexual roles, and these tools may be appropriated into sexual interactions at strategic moments. A condom, for example, can facilitate a sexual encounter in all sorts of ways — not just in preventing STDs: It can make someone a more desirable or less desirable partner, for example, or it can signal in the ongoing 
course of a sexual interaction that a certain stage has been reached; it can function as a question, or an invitation, or a warning, depending on the local situational context and the broader sociocultural environment in which it is introduced. Furthermore, because all 'mediational means' appropriated to 'do' sex embody different affordances and constraints and carry the histories of their past use, sex is always a site for the technologization of social practices and social identities and for the production and reproduction of ideologies and Discourses.

Nowadays, advances in information communication technologies have made available a whole new array of tools through which sex and sexuality can be mediated, and thus have made possible a whole new array of social actions that count as 'sex', including 'phone sex' (Hall 1995; Stone 1996), 'sexting' (Hasinoff 2012), and text-based and televideo cybersex (Jones 2008; Waskul 1994). These new tools affect not just the way people conduct digitally mediated sexual interactions, but also how they conduct sexual interactions offline as well. Kane Race (2015:271) goes so far as to argue that computers and mobile phones have given rise to "a historically distinctive way of arranging erotic and intimate life," a new "infrastructure of intimacy" with unique "erotic, social and communal potentials." It goes without saying that understanding how these new tools affect the kinds of actions people can take around sex and sexuality, the kinds of identities they can claim, and the kinds of ideologies they can promote is of great interest to mediated discourse analysts.

One of the most important characteristics of communication technologies (and one that is especially relevant when it comes to sex) is that they not only serve as mediational means in their own right, affecting who can communicate with whom, where and when, and using what semiotic modes (Jones 2005, 2016), but they also serve as means through which other cultural tools can be 'manufactured' though the process of recording and preserving people's words and 
actions. Information communication technologies belong to a special class of technologies that might be called 'technologies of entextualization' (among which we can include pens, paint brushes, printing presses, and cameras) (Jones 2009). The 'texts' that are produced as a result of using communication technologies can come to be used and technologized within the interactions in which they are created, or they can also be recontextualized into different interactions to take actions that may be quite foreign to the ways they were used in their original contexts. A somewhat ironic example of this is pointed out by Amy Hasinoff (2012: 450), who observes that although consensual sex between two 17 -year-olds is legal in most states, by sharing texts and images in the context of computer mediated sexting, these teenagers are violating the law against producing and distributing 'child pornography'. The problem is not the actions they are engaged in when they are 'sexting'; it is the entextualization of those actions that come as a byproduct of using the communication technology to perform them.

One of the main consequences of new communication technologies, then, is that they allow people to entextualize their bodies and bodily actions in new ways, and then to use these representations of their bodies as tools to take social actions, one of the most common manifestations of this affordance being the 'dick pic'. The production and distribution of dick pics and other representations of the body is the subject of a number of studies using tools from mediated discourse analysis. One of these studies explores the exchange of images in the context of text based communication in a gay chatroom (Jones 2005), another the regulation of access to images in the context of gay dating sites like Gaydar (Jones 2012), and a third the way gay men who engage in televideo cybersex (or 'cam sex') use the affordances of the technology to regulate the way they reveal and conceal different parts of their bodies in the course of the interaction (Jones 2008). 
Like the study on the use of condoms by gay men in China described above, these studies reveal that the way people use cultural tools in the course of sexual interaction can be complex and sometimes unexpected, and that these uses serve not just to perform social actions at the local level, but also to link these actions to broader ideologies about sex and sexuality. Just as a condom is never just a condom, a dick pic is never just a dick pic. When gay men exchange photos of themselves in text-based chatrooms, for example, whether photos of their penises, their torsos, their faces, or any other part of their bodies, they use these images to accomplish a range of different social actions. One of the most important, of course, is managing the negotiation of mutual attraction: they want to see what their potential sexual partner looks like before meeting up. At the same time, the images they exchange also serve as a means for them to manage difficult issues of disclosure and anonymity when chatting with strangers: one reason a man might choose to send a dick pic might be to avoid (or delay) sending a picture of his face, which obviously entails much more risk. In this regard, one of the key affordances of the dick pic in this context is that it allows for an incremental disclosure of identity: men often offer their bodies 'a piece at a time' as they gradually negotiate their relationships. Finally, in the course of these negotiations, the exchange of pictures serves as means of regulating a 'code of reciprocity' whereby the offer of a particular kind of picture opens a slot for the exchange of a similar kind of picture from the other party, and the kind of picture offered (whether it be a 'dick pic' or a 'face pic') can signal the direction in which the relationship is headed. In many of these encounters, then, a key site for the establishment of mutual trust and the exercise of power is on the micro level of conversational management as men vie to avoid being the first to offer a picture or work to ensure that their offer of a picture will be reciprocated.

A similar phenomenon is seen in televideo cybersex, where pointing one's camera at 
different parts of one's body acts as a way not just to entice and stimulate one's partner, but also to manage one's identity and regulate locally produced power dynamics. Participants in such encounters, for example, often take pains to make sure that when they offer a display of a particular body part (their penis or their face) that their interlocutor offers a reciprocal display (see excerpts 1-3).

\section{Excerpt 1}

A: show dick?

Wow nice

B: show yours

$\mathrm{mmm}$

Excerpt 2

A: you hard

down there?

B: LIKE A ROCK

\section{Excerpt 3}

A: wanna show face (displaying torso)

B: together (displaying torso)

A: ok

B: ready? (moving camera slowly upwards)

A: (moves camera upward to reveal face) ok thanks (quickly moves camera downward to display torso)

B: (moves camera downward to display torso) ur cute

A: really?

B: yeah

From Jones 2008: 465

Looking so closely at the way people negotiate the moment by moment exchange of images of their penis online may, on one level, seem trivial given the important issues of marginalization and institutional discrimination that scholars of language and sexuality need to deal with. It is, 
however, through these careful negotiations of discourse identities (Scollon 1996) that broader social identities and social relationships are constituted. When and how one displays one's penis in such interactions serves to construct the owners of those penises as having certain moral characteristics (like trustworthiness), of being qualified to take on certain technologized sex roles (like 'top' or 'bottom'), and of being the kinds of people you might imagine having a certain kind of relationship with. As one of the participants in Jones (2005) put it:

I like to see the person's face when I chat on cam. If we get along, we might meet up for real later on. On the other hand, I would never show my face if I am having cybersex. It's too embarrassing. And I won't meet up with someone who is willing to do that kind of thing on cam. (88)

Often in studies of language and sexuality when we speak of power, we think of it on the macro level, in terms of things like institutional discrimination or gender-based hegemony. Examining sex and sexuality at the level of the situated social action, on the other hand, allows us to observe how power manifests in the moment by moment claims and imputations of identity that people engage in when they appropriate cultural tools. Since these tools (and the identities claimed through them) always index larger 'toolkits' (Discourses), mediated discourse analysis give us a way of seeing how micro operations of power are always related to macro (societal, institutional) relations of power.

This relationship between the deployment of digital images and the management of social identities has also been observed in more recent studies of mobile 'hookup apps' like Grindr. Although these studies do not make explicit use of mediated discourse analysis, many of them 
share a similar perspective on the importance of examining how mediational means make particular kinds of social interactions, social relationships, and social identities possible. Kane Race (2015), for example, focuses on "how electronic devices and software ...mediate the sexual encounter in new ways; making certain activities, relations, and practices possible while obviating others." The way people deploy photos using 'hookup apps', he observes, serves not just to attract certain kinds of sexual partners, but also helps to construct the infrastructure for sexual encounters people have once they meet up in 'real life'. Similarly, Courtney Blackwell and her colleagues (2015) examine how users of gay hookup apps use photos as cues to signal particular interactional intentions, and Evangelos Tazallis (2015) describes how pictures sometimes operate as conversational moves in 'gamified' interactions that facilitate not just hookups but also a kind of 'pornified' identity play in which "deeply inscribed (racial, bodily, gender, class) hierarchies within the gay male community" are rehearsed and reinscribed (767).

Nowhere, however, is the power dimension of image sharing more obvious than in studies of how heterosexual adolescents exchange pictures of themselves while 'sexting' (see for example Hasinoff 2012; Lippman \& Campbell 2014; Ringrose 2011; Ringrose and Harvey 2015). The most important thing these studies reveal is that 'sexting' is not just about sex, and that, like the gay men in the studies described above, teenagers accomplish a range of social actions through producing and exchanging sexy pictures of themselves. Amy Hasinoff (2012), for example, regards sexting as a form of 'media production' through which adolescent girls manage their social relationships with peers of both genders and engage in often creative forms of identity play, which sometimes serve to challenge or critique media portrayals of women. Examining the sharing of sexy images on the more micro level, Jessica Ringrose and her colleagues (Ringrose 2011; Ringrose and Harvey 2015) describe how the management of 
requests by boys of images of girls' breasts involves complex claims and imputations of identity through which girls need to negotiate the fine line between being seen as desirable and being seen as a 'slut', and how, in such contexts, the identity of 'slut' itself can take on a new 'exchange value', signaling sexual confidence, experience, and knowingness. So, while girls in these interactions are, as Ringrose (2011:111), citing Gill (2008), puts it, "under pressures to visually display and perform a new 'compulsory' disciplinary technology of sexy” (Gill 2008), the material technologies of mobile phones seem to give them opportunities to, to some degree, disrupt this discipline and the relationships of power it entails.

At the same time, in nearly all studies of adolescent sexting there is overwhelming evidence that the way images of different body parts are regarded reproduces well established gender based stereotypes and hierarchies. As Salter (2015) observes, images of the exposed female body almost always expose their producers to "pejorative ascriptions of sexual promiscuity," regardless of the contexts in which these images are produced and exchanged, while images of the male body are rarely subject to such ascription. At the same time, males use images of their bodies (and images of the female bodies they have gained access to) in more aggressive ways - for example, as tools for sexual harassment or as emblems of conquest. Ringrose and her colleagues (Ringrose et al., 2013), for example, observe how images of girls' bodies function in a competitive system of peer 'ratings' in which boys could gain value by tagging, collecting, and showing images they claimed were sent to them by the girl. Thus, practices of exchanging images of the body become 'technologized' in ways that reproduce dominant discourse of masculinity and femininity. These practices, of course, take place against the backdrop of larger media discourses that technologize sexting in similar gendered ways, ignoring the agency of women in negotiating their own privacy rights and calling for solutions 
involving even more intrusive forms of surveillance by parents, schools, or internet companies themselves (Draper 2012).

\section{APPROPRIATION, RECONTEXTUALIZATION, AND THE HISTORICAL BODY}

In the last section I argued that a key affordance of digital technology is that it provides new ways for people to 'entextualize' themselves and to use these textual selves as tools to engage in a range of social practices. In this section, I will take this notion even further, arguing that the way we become sexual selves is intimately tied up with the ways our cultural tools make possible particular textual selves, and that, through mediated actions using texts, we act to define the contours of our agency.

Who we can be and what we can do when it comes to sex and sexuality is not entirely up to us. We author our sexual selves using the tools and texts our sociocultural environments make available to us, and, like all other cultural tools, they come with built in affordances and constraints. That is not to say that we simply mimic sets of pre-fabricated identities, relationships, and practices. Rather, we appropriate, sometimes in creative ways, the tools that are available to us and adapt them to our own goals and purposes. This idea of 'appropriation' comes from Mikhail Bakhtin (1981), who insisted that speaking inherently involves appropriating the words of others and somehow making them our own. Words, like all cultural tools, are not neutral. They exist first in the mouths of others, relevant to their contexts and serving their intentions. So appropriation is always a matter of, to some extent, 'buying into' the discourses from which we have borrowed our tools, and, at the same time, resisting these discourses in order to make these tools fit our particular purposes.

A good example of this can be seen in a study that used mediated discourse analysis to 
analyze the narratives gay men told of their sexual encounters (Jones 2007b; Jones and Candlin 2003). In relating the story of his 'first time', one participant talked about how he appropriated a media text about a man being arrested for public sex in order to facilitate his own mastery of the practice of 'cruising'; He said:

When I was studying at F3 or 4. I read a magazine article which mentioned about a homosexual got arrested because of his indecent behaviour in the public toilet in Jordan. The article also reported on all the public toilets in Hong Kong which were very popular among gay people. After reading the article I could hardly wait and decided to go to the toilet in Shamshipo on Saturday in the same week... when I got there. I saw some men at the cubicles, some were at the urinal. I walked to the washing basin and started washing my hands and looked at the mirror as the article described about how gay men cruise in the toilet. I saw a man in his 20 s, he looked at me in the mirror and signalled us to leave together. I followed him...Before we parted, he talked to me sincerely for a while: 'The gay circle is very complicated and you need to be careful. Police may come in at any time; play safe and don't get an STD ...' He gave me his telephone number then left. On my way home, I was still recalling what had just happened. I asked myself if he would get AIDS because he had sucked my dick. But I didn't think he would. I kept wishing that I would have more similar experiences in the future. I want the thrill, the excitement. Since then, whenever I have time, I would look and cruise around. (Jones 2007b: 251)

Again, as with the example with which I began this chapter, we see a cultural tool being appropriated in a way that is very different from the way it was intended, the narrator making use of a magazine article describing an illegal activity in order to actually learn how to engage in that 
activity. In his story, he explicitly relates how he used the information in the article both to locate a particular public toilet known as a public sex venue, and to engage in tactics for attracting the attention of a possible sexual partner. Of course, this example is one of many instances where gay men have appropriated tools from dominant (often overtly homophobic) discourses and 'queered' them. But what is important about such acts of appropriation is not just the way they are used strategically to perform particular actions, but also how they create the conditions for future actions. When we appropriate cultural tools, we rarely set them down when we are finished with them. Especially if we use them continually, they come to be submerged in what, in mediated discourse analysis, is known as 'the historical body' (Jones 2007b; Scollon 2001), the storehouse of experiences and 'practiced practices' which we draw upon to take future actions. The practices the narrator of the story above learns about from the magazine article and recontextualizes into his first attempt at cruising will subsequently be repeated, practiced, and refined through trial and error. They will become 'part of him', helping to determine his future actions while 'cruising around'. But what also will become part of his 'historical body' is the sense of danger (and perhaps shame) communicated in that article, which, after all, is about the arrest of a gay man for public sex, a sense of danger that is reinforced in the warnings that his first sexual partner gives him ('you need to be careful. Police may come in at any time...'), and which, may actually contribute to the 'thrill and excitement' of the practice going forward.

The point that I am trying to make with this discussion is that our strategic appropriation of the cultural tools that our society provides for us to take mediated actions is not just the way we 'get things done', but also the process through which we author ourselves, 'writing' our historical bodies with the words of others. And so, while such acts of appropriation are often radical acts of agency in which we are actually resisting the discourses from which these tools 
were appropriated by recontextualizing them into situations for which they may not have been intended, we also must continue to carry the burden of the histories of these tools and practices (sometimes involving constraints on future actions) that become sedimented into our historical bodies. At the same time, the ability to appropriate and recontextualize cultural tools is unequally distributed, based on various kinds of power, privilege, differential legitimacy in claims to use certain tools, differential competence in using them, and different values that adhere to different tools in different communities (Bauman \& Briggs 1990).

The issues of agency and power associated with processes of appropriation are particularly salient in cases where people 'lose control' of their sexual/textual selves, where the bodily traces they have left through mediated sexual encounters are appropriated by others in ways that they never expected. In such cases, another dimension of the historical body becomes salient: the histories of our accumulated acts of appropriation that we leave on the environments and in the minds of others. In the past such traces consisted perhaps of letters, snapshots, stories passed on by word of mouth, media reports, and other texts that came to influence people's reputations or 'public histories'. This externalized historical body can be just as central in determining matters of individual agency as the storehouse of practices and identities that one has built up internally through the incremental performance of mediated actions. Just as we can only operate using the tools and practice that we have appropriated from our social worlds, we can also only operate within the contours of the histories of ourselves that we have created in the minds of other people and in the trail of texts that support these histories (such as drivers licences, diplomas, criminal records). With the rise of digital technologies, the nature and persistence of this external historical body has changed dramatically, both as a result of the promotion of digital practices of 'sharing' aspects of oneself (including images of one's body) 
online (see above), and as a result of the constant surveillance of internet users by companies for commercial purposes and by governments for security purposes. These externalized 'historical bodies' take on many textual and material forms including stored CCTV footage, government records, databases held by telecom companies of all of our phone calls and the physical locations that have been logged by our phones' GPS systems, the accumulated posts that we have 'liked' on social media sites, our internet searches and purchases from companies like Amazon.com, and pictures we upload or exchange over the network (including dick pics) (Jones 2017).

These bodies have been famously referred to by Kevin Haggerty and Richard Ericson (2000) as 'data doubles'. The most important aspect of these 'data doubles' is their potential to rob people of agency by denying them control over how their textual selves are recontextualized. Of course, this is not just a problem with digital technologies. People have been struggling with the consequences of the ways their textual selves are recontextualized by others ever since humans began gossiping. Digital technologies, however, with their affordances for easily entextualizing bodies and circulating these texts rapidly though networks has made these consequences even more salient in public discourse around sex and sexuality. Media and educational materials, for example, often warn girls against sexting, lest the images they produce 'go viral' and ruin their reputations (see for example Child Exploitation and Online Protection Centre 2011). This is also the point that Oliver makes in his humorous tirade about the NSA keeping dossiers of citizen's dick pics (though the social consequences of this for producers of such images are much less clear).

The most dramatic example of sexual/textual selves being used for purposes for which they were not originally intended is revenge porn, the practice of people distributing - often via websites dedicated to this purpose -- intimate images and videos of other people, usually former 
lovers, without their consent, in order to exact vengeance for perceived wrongs. On such sites, photos and videos are generally posted with the full names of the person pictured along with a short narrative about why that person has been exposed, accounts which usually attempt to position the poster as the true victim. Excerpts 4 and 5 show two such narratives from the website Myex.com.

\section{Excerpt 4}

I considered her a friend and we hooked up

a few times. Long story

short....whore took a couple hundred from

my wallet and my HSA (Health Savings

Account) card. Haven't seen her since.

Everything she told me was a lie.

From Myex.com, quoted in Jones, 2016

\section{Excerpt 5}

When she was my girlfriend, I didn't knew she had 4 other boyfriends. I wish she is dead. I really, really loved her, like I've never loved anyone else in this miserable worl. She obliderated (sic) my heart.

In such contexts, the most obvious social action that these images are being used to perform is what Tannenbaum (2015) calls 'slut shaming'. This action is made possible, however, not just through the exposure of intimate photographs, but through the technologization of the identity of the 'slut' by using an array of discursive tools, including master narratives of moral turpitude which stories like those cited above invoke, and a collection of gendered terms of abuse. For example, in a corpus of 500 revenge porn stories collected about women whose pictures had been uploaded to Myex.com (Jones 2016), the most frequent words used to describe these women were 'bitch', 'slut', and 'whore'. At the same time, a similar corpus from the (much 
smaller) section of the site where pictures of men were uploaded contained few specific terms of abuse. Instead, stories about men focused on what they had done-like 'lie' and 'cheat' and 'fuck'. When they were labeled, it was with more innocuous terms like 'guy', 'cheater', 'player', or, at worst, 'asshole'. Of course this double standard should not be surprising, reflecting as it does broader discursive practices of gendered labeling. The important point here is that these images themselves are not intrinsically 'shameful', and indeed, the contexts in which they were originally produced made very different kinds of social actions and different kinds of social identities possible both for the people depicted in them and the people that they shared them with. When they are reappropriated into Myex.com, therefore, they are not just recontextualized, they are also retechnologized, brought into a relationship with a new set of cultural tools and made part of a different discourse.

It would be a mistake, however, to think that people who upload pictures of their exlovers on revenge porn sites are just 'taking revenge', just as it is a mistake to think that adolescent sexting is just about sex. Within the context of these sites, these images are used to accomplish a variety of social actions among the users of the site, including claiming identities for themselves as both victims and 'victors', performing masculinity, competing for social status, and engaging in homosocial bonding through sexual storytelling and the sharing of pornography (Flood 2008).

The range of these activities becomes clear when one examines the comments sections of Myex.com, where visitors discuss the images that have been uploaded and the stories attached to them. What is interesting about these discussions is that, while they are replete with (mostly abusive) assessments of the people depicted in the images, they are also full of (mostly abusive) assessments of the original posters of these images, assessments regarding the quality of their 
images, their choice of sexual partners, and their own role in bringing about their alleged victimhood. Most of these assessments involve the same degree of name calling to which the women in the images are subjected, comments such as: 'op [original poster] is a fucktard,' 'op is an asshole,' 'op is a dick sucking homo,' and 'op should jump off the nearest cliff.'

One of the ironies of 'taking revenge' though exposing sexy images of a former partner is that often such images also depict the poster himself, and so by exposing their victims, posters also end up exposing themselves, and it is these acts of exposure that are among the most frequent targets of abuse from commenters, abuse which takes the form of remarks like 'aw you got a baby dick son how do you manage to sleep with anyone with that? and small pathetic cock?' and 'hahahaha first thing I saw was your cock and it's small.' And so, even in the context of shaming their ex-girlfriends and trading porn, these men are also engaged in the action of exchanging dick pics, and subject to the claims and imputation of social identity, and to the invocations of broader discourses of masculinity this entails.

\section{CONCLUSION: SEXUALITY AND THE TECHNOLOGIZATION OF THE BODY}

Sexuality emerges through a process of making our bodies (and parts of our bodies) meaningful in the ongoing negotiation of social interaction. This process is made possible by the range of cultural tools that our societies make available to us, which include both semiotic tools like narratives, forms of address, terms of abuse and conversational gambits, and material tools like condoms, computers, and dick pics. The way we use these tools to take actions ends up both determining the kinds of identities we can claim for ourselves and impute on others, identities like 'gay man' and 'slut', and recreating broader social values and expectations about what kinds of people ought to be able to take what kinds of actions in particular social contexts. 
In a recent article in First Monday, Nishant Shah (2015) claims that on the internet we are all sluts, that there is something inherent in the affordances of digital technologies for "exposure, repetition, sharing, replication, and uncontrolled proliferation" that reconfigures our bodies and our genders. "To be digital," she says, "is to be slutty." If this is the case, she goes on, the important question to ask is: "Why are only certain kinds of slutty bodies punished?" What are the discursive mechanisms though which slutty identities are policed, contained, challenged and ascribed?

One way to answer this question is to begin with the broader discourses and ideologies of gender and sexuality that operate in a particular society and explore how they are reproduced in people's language and in their practices. Mediated discourse analysis offers another way of going about answering this question, by focusing on the ways identities are claimed and imputed through the moment by moment concrete social actions people take using the range of cultural tools, both material and semiotic, their societies make available to them.

\section{REFERENCES}

Agha, Asif. 2007. Language and social relations. Cambridge ; New York: Cambridge University Press.

Bakhtin, Mikhail M. 1981. The dialogic imagination: Four essays. (M. Holquist, Ed., C. Emerson, Trans.). Austin: University of Texas Press.

Bauman, Richard, \& Briggs, Charles L. 1990. Poetics and performance as critical perspectives on language and social life. Annual Review of Anthropology 19: 59-88. 
Blackwell, Courtney, Birnholtz, Jeremy, \& Abbott, Charles. 2015. Seeing and being seen: Cosituation and impression formation using Grindr, a location-aware gay dating app. New Media \& Society 17: 1-20

Bucholtz, Mary \& Hall, Kira. 2016. Embodied sociolinguistics. In Sociolinguistics: Theoretical debates. ed. Nikolas Coupland, 173-199. Cambridge: Cambridge University Press.

Child Exploitation and Online Protection Centre. 2011. Exposed. Retrieved 16 May 2018, from https://www.youtube.com/watch?v=4ovR3FF_6us

Douglas, Mary. 1970. Natural symbols: Explorations in cosmology. New York and London: Routledge.

Draper, Nora R. A. 2012. Is Your Teen at Risk? Discourses of adolescent sexting in United States television news. Journal of Children and Media 6: 221-236.

Fairclough, Norman. 1992. Discourse and social change. Oxford: Polity Press.

Flood, Michael. 2008. Men, sex, and homosociality: How bonds between men shape their sexual relations with women. Men and Masculinities 10: 339-359.

Gee, James Paul. 2011. Social linguistics and literacies: Ideology in discourses (4th ed.). London: Routledge.

Gibson, James J. (1986). The ecological approach to visual perception. Boston: Psychology Press.

Gill, Rosalind. 2009. Supersexualize Me! Advertising and the "Midriffs. In Mainstreaming sex. eds. Feona Attwood, 93-109. London: I. B. Tauris.

Gorenstein, Colin. 2015, April 9. 'Dick pics for freedom': How John Oliver accidentally started a NSFW revolution. Retrieved 16 May 2018, from 


\section{https://www.salon.com/2015/04/09/dick_pics_for_freedom_how_john_oliver_accidentall}

\section{y_started_a_nsfw_revolution/}

Haggerty, Kevin D., \& Ericson, Richard V. 2000. The surveillant assemblage. British Journal of Sociology 51: 605-622.

Hall, Kira. 1995. Lip service on the fantasy lines. In. Gender articulated: language and the socially constructed self. eds. Kira Hall \& Mary Bucholtz, 183-216. New York: Routledge.

Hasinoff, Amy A. 2012. Sexting as media production: Rethinking social media and sexuality. New Media \& Society 15: 449-465.

Jones, Rodney. H. 1999. Mediated action and sexual risk: Searching for 'culture' in discourses of homosexuality and AIDS prevention in China. Culture, Health \& Sexuality 1: 161-180.

Jones, Rodney. H. 2002. Mediated action and sexual risk: Discourses of sexuality and AIDS in the People's Republic of China. Unpublished PhD. Dissertation, Macquarie University, Sydney.

Jones, Rodney H. 2005. 'You show me yours, I'll show you mine': the negotiation of shifts from textual to visual modes in computer-mediated interaction among gay men. Visual Communication 4: 69-92.

Jones, Rodney. H. 2007a. Imagined comrades and imaginary protections: Identity, community and sexual risk among men who have sex with men in China. Journal of Homosexuality $53: 83-115$.

Jones, Rodney H. 2007b. Good sex and bad karma: Discourse and the historical body. In Advances in Discourse Studies. eds. Vijay K. Bhatia, John Flowerdew \& Rodney H. Jones, 245-57. London: Routledge. 
Jones, Rodney. H. 2008. The role of text in televideo cybersex. Text \& Talk, 28: 453-473.

Jones, R. H. 2009. Dancing, skating and sex: Action and text in the digital age. Journal of Applied Linguistics 6:283-302.

Jones, Rodney. H. 2012. Constructing and consuming 'displays' in online environments. In Multimodality in practice: Investigating theory-in-practice-through-methodology. ed. Sigrid Norris, 82-96. New York: Routledge.

Jones, Rodney H. 2016a. Spoken discourse. London: Bloomsbury.

Jones, Rodney H. 2016b. Pornography, anonymity and surveillance. A paper delivered at Sociolinguistics Symposium 21, Murcia, Spain, June 15-18.

Jones, Rodney H. 2017. Surveillant landscapes. Linguistic Landscape 3: 149-186.

Jones, Rodney H. (in press). The rise of the pragmatic web: Implications for rethinking meaning and interaction. In Historicising the digital. eds. Caroline Tagg and Melanie Evans. Amsterdam: De Gruyter Mouton.

Jones, Rodney H. \& Candlin, Christopher N. 2003. Constructing risk along timescales and trajectories: Gay men's stories of sexual encounters. Health, Risk and Society 5: 199-213.

Jones, Rodney. H., \& Hafner, Christoph A. 2012. Understanding digital literacies: A practical introduction. London: Routledge.

Jones, Rodney. H. \& Norris, Sigrid. 2005. Discourse as action/Discourse in action. In Discourse in action: Introducing mediated discourse analysis. eds. Sigrid Norris and Rodney H. Jones, 3-14. London: Routledge.

Lippman, Julia R., \& Campbell, Scott W. 2014. Damned If You Do, Damned If You Don’t...If You're a Girl: Relational and normative contexts of adolescent sexting in the United States. Journal of Children and Media 8: 371-386. 
Livia, Anna, \& Hall, Kira. 1997. 'It's a girl': Bringing performativity back into linguistics. In Queerly phrased: Language, gender, and sexuality. eds. Anna Livia and Kira Hall, 3-18. New York: Oxford University Press.

Nagel, Joane. 1998. Masculinity and nationalism: gender and sexuality in the making of nations. Ethnic and Racial Studies 21: 242-269.

Norris, Sigrid \& Jones, Rodney H. (eds.). 2005. Discourse in action: Introducing mediated discourse analysis. London: Routledge.

Paul, James C. N. 1961. The Post Office and non-mailability of obscenity: An historical note. UCLA Law Review 8: 44.

Race, Kane. 2015. 'Party and Play': Online hook-up devices and the emergence of PNP practices among gay men. Sexualities, 18: 253-275.

Rofel, Lisa. 1999. Other modernities: Gendered yearnings in China after socialism. Berkeley: University of California Press.

Ringrose, Jessica. 2011. ‘Are You Sexy, Flirty or a Slut?’ Exploring ‘sexualization’ and how teen girls perform/negotiate digital sexual identity on social networking sites. In New femininities: Postfeminism, neoliberalism and identity. eds. Rosalind Gill and Christina Scharff, 99-116. London: Palgrave.

Ringrose, Jessica \& Harvey, Laura. (2015). Boobs, back-off, six packs and bits: Mediated body parts, gendered reward, and sexual shame in teens' sexting images. Continuит: Journal of Media \& Cultural Studies: 29: 205-217.

Ringrose, Jessica, Harvey, Laura, Gill, Rosalind, \& Livingstone, Sonia. 2013. Teen girls, sexual double standards and 'sexting': Gendered value in digital image exchange. Feminist Theory, 14: 305-323. 
Salter, Michael. 2015. Privates in the online public: Sex(ting) and reputation on social media. New Media \& Society, Published online before print September 7, 2015.

Scollon, R. 1996. Discourse identity, social identity and confusion in intercultural communication. Intercultural Communication Studies 6: 1-16.

Scollon, R. 2001. Mediated discourse: The nexus of practice. London: Routledge.

Shah, Nishant. 2015. Sluts 'r' us: Intersections of gender, protocol and agency in the digital age. First Monday, 20(4). Retrieved from http://firstmonday.org/ojs/index.php/fm/article/view/5463

Silverstein, Michael. (2003). Indexical order and the dialectics of sociolinguistic life. Language \& Communication 23: 193-229.

Stone, Allucquère Rosanne. 1996. The war of desire and technology at the close of the mechanical age. Cambridge, MA: MIT Press.

Tanenbaum, Leora. (2015). I am not a slut: Slut-shaming in the age of the internet. New York: Harper and Row.

Tziallas, Evangelos. 2015. Gamified eroticism: Gay Male 'Social Networking’ Applications and Self-Pornography. Sexuality \& Culture 19: 759-775.

Waskul, Dennis D. 2003. Self-Games and body-play: Personhood in online chat and cybersex. New York: Peter Lang Publishing Inc.

Wertsch, James V. 1994. The primacy of mediated action in sociocultural studies. Mind, Culture, and Activity 1: 202-208.

Wertsch, James V. (1998). Mind as action. New York: Oxford University Press. 